УДК 376.37

\title{
НАРУШЕНИЕ СЛОГОВОЙ СТРУКТУРЫ СЛОВА У СТАРШИХ ДОШКОЛЬНИКОВ С ОБЩИМ НЕДОРАЗВИТИЕМ РЕЧИ
}

\author{
Стрекатова Татьяна Анатольевна \\ магистрант \\ Научный руководитель: Шамовская Татьяна Владимировна \\ к.ф.н., доцент \\ ФГБОУ ВПО «Кемеровский государственный университет»
}

\begin{abstract}
Аннотация: В статье рассматривается актуальная проблема - нарушение слоговой структуры слова у старших дошкольников с общим недоразвитием речи, взаимосвязь искажения слова с уровнем речевого недоразвития ребенка и его характером.
\end{abstract}

Ключевые слова: слог, слоговая структура слова, общее недоразвитие речи, обучение грамоте, дошкольный возраст.

\section{VIOLATION OF THE SYLLABIC STRUCTURE OF THE WORD IN OLDER PRESCHOOLERS WITH GENERAL SPEECH UNDERDEVELOPMENT}

\section{Strekatova Tatiana Anatolyevna Scientific adviser: Shamovskaya Tatiana Vladimirovna}

\begin{abstract}
The article deals with an urgent problem - a violation of the syllabic structure of the word in older preschoolers with general speech underdevelopment, the relationship of word distortion from the level of speech underdevelopment of the child and from his character.

Key words: syllable, syllabic structure of the word, general underdevelopment of speech, literacy, preschool age.

Ежегодно увеличивается число детей старшего дошкольного возраста с речевым заключением «Общее недоразвитие речи». У большинства из них в той или иной степени присутствуют нарушения слоговой структуры слова, которые признаны ведущими и стойкими. Очевидно, что наличие специфических ошибок в слоговой структуре слова мешают нормальному развитию устной речи дошкольников с общим недоразвитие речи, затрудняют
\end{abstract}


их общение, а также препятствуют звуковому анализу и, следовательно, обучению грамоте. А это значит, что недостаточная коррекция данного вида патологии в дошкольном возрасте впоследствии приводит к возникновению у школьников дислексии и специфических дисграфических ошибок на письме.

Поэтому, проблема нарушений слоговой структуры слова и ее освоение у старших дошкольников с общим недоразвитием речи актуальна в настоящее время.

Под термином «общее недоразвитие речи» принято понимать сложное речевое расстройство, характеризующее речевую функцию как неполноценную и все конструкции языка, такие как лексическая, грамматическая и фонематическая, отличаются несформированностью. У дошкольников с общим недоразвитием речи наблюдается бедность активного и пассивного словаря, отсюда неточность и сложность в употреблении слов, часто наблюдаются недостатки звукопроизношения и специфические ошибки в слоговой структуре слова.

Многие ученые, такие как Л.С. Волкова, Р.И. Лалаева, А.К. Маркова, а также анализ данных научной литературы по проблемам нарушения и коррекции слоговой структуры слова у детей дошкольного возраста позволяет сделать вывод о том, что процесс усвоения слогового состава напрямую связан с речевым развитием ребенка. По типу нарушений слоговой структуры слова можно диагностировать уровень речевого развития [1, с. 87]. Значит, процесс усвоения слогового состава слова тесно связан с речевым развитием в целом и с состоянием фонематических или моторных (артикуляционных) возможностей ребенка в частности [2, с.168].

Это же подтверждают и многие авторы-исследователи, такие как 3.Е. Агранович, С.Е. Большакова, Т.А. Ткаченко, Н.С. Четверушкина. Они отмечают, что нарушения слоговой структуры у детей старшего дошкольного возраста с общим недоразвитием речи 2 уровня проявлялись, как правило, в сокращении количество слогов, пропусках согласных звуков в стечениях и это свидетельствует о первичном недоразвитии слухового восприятия детей. При общем недоразвитии 3 уровня преобладают ошибки, которые выражены в сокращение количества слогов, уподобление слогов друг другу, сокращение стечений согласных и указывают на преимущественное нарушение в артикуляционной сфере ребенка.

Следовательно, основополагающий диагностический показатель в структуре общего речевого нарушения - это множественные специфические 
ошибки слоговой структуры слова, которые характеризуются трудностями в произношении слов сложного слогового состава.

Таким образом, искажение слова обусловлено спецификой и уровнем речевого недоразвития и зависят от его характера. То есть, недостаточность, бедность активного словаря в свою очередь, задерживает формирование слоговой структуры слова, а специфические особенности слоговой структуры слова у детей старшего дошкольного возраста с общим недоразвитием речи проявляются в наличии пропусков и вариативности ошибок в произношении слов слогового состава разной степени сложности. В одних случаях недоразвитие речи влияет на недостатки овладения слоговым составом слова через отклонения в сенсорной сфере и возникающие вследствие этого трудности в различении слоговых контуров. В других же случаях ввиду несформированности артикуляционной сферы возникают затруднения в воспроизведении слоговых контуров, в слиянии разных слоговых рядов.

Описанные выше особенности освоения и формирования слоговой структуры слова однозначно тормозят нормальное развитие устной речи (накопление словаря, усвоение понятий и т.д.) и усложняют общение детей, а также, несомненно, затрудняют развитие звукового анализа и синтеза, и следовательно, мешают дошкольнику в освоение грамоте.

Так как у детей с тяжёлыми нарушениями речи слоговая структура слова имеет выраженные отклонения, то очевидно, что долгий процесс «стихийного» формирования слоговой структуры слова необходимо заменить сознательным и целенаправленным процессом обучения.

То есть, для успешной и своевременной коррекции всех недостатков устной речи, а в частности устранения нарушений слоговой структуры слова в дошкольном возрасте необходимо учитывать её развитие в онтогенезе. Коррекционная работа по устранению нарушений слоговой структуры слова не должна ограничиваться только лишь задачей исправления данного недостатка, она должна быть развивающей и включать в себя работу над словарным запасом, грамматическими формами, фонематическим восприятием, развитием интеллектуальных функций (мышления, памяти, внимания). 


\section{Список литературы}

1. Левина, Р.Е. Нарушение слоговой структуры слова у детей // Р.Е. Левина. - Специальная школа. - 1959. - № 4. С. 86-89.

2. Мархандаева, Г.И. Выявление нарушений слоговой структуры слова у дошкольников с общим недоразвитием речи и пути их коррекции / Г.И. Мархандаева. // Молодой ученый. - 2020. - № 9 (299). - С. 167-168. - URL: https://moluch.ru/archive/299/67767/ (дата обращения: 07.11.2021).

3. Агранович, 3.Е. Коррекция нарушений звуко-слоговой структуры слов у детей / 3.Е. Агранович.- СПб.: Детство-Пресс, 2014. - 66 с.

4. Бабина, Г.В., Сафонкина Н.Ю. Слоговая структура слова: обследование и формирование у детей с недоразвитием речи: учеб.-метод. пособие. - М.: Книголюб, 2005. - 96 с. 